DOI: $10.19195 / 0137-1134.115 .9$

\author{
JOANNA HELIOS \\ ORCID: 0000-0003-3571-1665 \\ Uniwersytet Wrocławski \\ WIOLETTA JEDLECKA \\ ORCID: 0000-0002-0542-9303 \\ Uniwersytet Wrocławski
}

\title{
THE DERIVATIVE CONCEPT OF LEGAL INTERPRETATION IN EU LAW
}

\begin{abstract}
The derivative concept of legal interpretation of Zygmunt Ziembiński and Maciej Zieliński is one of the two normative concepts of legal interpretation, generated in the Polish post-war theory of law; the second one is the semantic intentional (clarification) concept, formulated by Jerzy Wróblewski. According to the doctrine, the legal interpretation made by the Court of Justice of EU should mirror the wide, validation-derivation approach to the legal interpretation. This is due to the specific character of the sources of the EU law, and due to the evident, in this case, validation element, which excludes the case of isomorphy. The considerations concerning validation issues, taking into account the versatility of the sources of EU law, are very valuable, especially in view of the fact that the sources of the EU law differ in large degree from the sources of the national law. Accepting the derivative concept of legal interpretation in the EU context, implies the rejection of the doctrine of acte clair which seems useful from the point of view of the development of the co-operation of the national courts with the CJEU. The application of the derivative approach seems irreconcilable with the doctrine of acte clair. On the other hand, the interpretation practice of the EU law, connected with the multiplicity of the bodies, who have played the legislation functions, the obligation for making pro-Community interpretations (friendly and uniform), the spread of technology, regarding the majority of the EU legal regulations, all create real challenges for the derivative concept.
\end{abstract}

Keywords: derivational interpretation, situation of interpretation, pro-Community interpretation, the acte clair doctrine, validation-derivation interpretation

\section{THE DERIVATIVE CONCEPT OF LEGAL INTERPRETATION IN THE POLISH THEORY OF LAW}

The derivative concept of legal interpretation of Zygmunt Ziembiński and Maciej Zieliński is one of the two normative concepts of legal interpretation, generated in the Polish post-war theory of law; the second is the semantic intentional 
(clarification) concept, formulated by Jerzy Wróblewski. ${ }^{1}$ The axial premise of the derivative concept of legal interpretation is the assumption stating that the legal norms are to be reconstructed by the interpreter from the legal provisions. This stems from the fundamental conceptual differentiation, which is made between a legal provision and a legal norm. In this approach, the language of the legal provisions is only a starting point in the complex process of determining the unequivocal legal norm. The final aim, on the other hand, that is being pursued, are the norms. Thus, the aim of the legal interpretation is not, in fact, the assessment of the proper meaning of the legal provisions. The essence is, that the law is equivalent to neither the normative acts, nor the legal provisions. The law is equivalent to legal norms, expressed (verbalized) in the legal provisions. ${ }^{2}$ The essence of the derivative concept of legal interpretation is translating the legal provisions into their equivalent legal norms, which is the aim of numerous interpretative operations. The legal interpretation should proceed along the scheme which encompasses the reshaping of a legal provision into a norm-shaping expression, and the following reshaping of the norm-shaping expression into a a legal norm - the norm which is the subject of direct perception. This is obtained with the aid of three phases of legal interpretation: ordering, reconstructing and perceptive. ${ }^{3}$ In the ordering phase the interpreter determines the scope of the legal provisions, submitted to the legal interpretation, and it is the interpreter who also determines the up-to-date character of the complex shape and the factual binding of the legal provisions, for the given moment of interpretation, which lies within his interest. In this phase, the interpreter has to mainly assess the issues, which are connected with particular legal provisions being in force, any changes within the texts of the normative acts, any changes in the text of the legal provisions, as well as any inter-temporal legal regulations. In the reconstruction phase, the role of the interpreter is the reconstruction, from the legal provisions, of the norm-shaping expression, which inheres in all the syntactic elements of the behaviour norm; all these elements of the behaviour norm do not have to be unequivocal at this stage. In the reconstruction phase, the interpreter settles the issues connected with the quasi-idiomatic feature of the language of the legal provisions, as well as with the specific techniques of the "encoding" of norms in the legal provisions, such as syntactic segmentation and meaning-content segmentation, as well as the condensation of the norms in the legal provisions. At the last stage - the perceptive stage - the task of the interpreter is to ascribe to all the constituent expressions of the norm-shaping ex-

1 O. Bogucki, Model wykładni funkcjonalnej w derywacyjnej koncepcji prawa, Szczecin 2016, pp. 15-16.

2 K. Siwek, "Komunikatywność tekstu prawnego a derywacyjna koncepcja wykładni prawa (aspekt rozumienia normy sankcjonowanej)", Ruch Prawniczy, Ekonomiczny i Socjologiczny 78, 2016, no. 4, pp. 71-72.

3 P. Brzeziński, "Konstytucyjne prawo do ochrony zdrowia w świetle derywacyjnej koncepcji wykładni”, Ruch Prawniczy, Ekonomiczny i Socjologiczny 73, 2011, no. 1, p. 39. 
pression, one unified meaning. His task is to approach the complex perceptions of a given norm, along with its meaning. At this stage, the interpreter has to assess the issues connected with ambiguities and underspecified fragments, the fuzziness (lack of sharpness) of the expressions in the texts of the legal acts. According to the derivative theory, the main burden of the problem lies in accumulating the elements of meaningful content, i.e. the elements which are necessary for the reconstructing of the (crucial) expression, which describes the general character of a particular behaviour norm. This must be done independently of the fact that the formulated definition, existing at this stage, of the addressee, the conditions, and the action, which is to be fulfilled, may not be clear enough, at the beginning ("non clara") - and this is when the need occurs to employ the traditional rules, formulated within the clarification concept of the legal interpretation. ${ }^{4}$

In the operative legal interpretation model, it is more useful to apply the derivative legal interpretation. The latter here means the ordering of the derivation subject, i.e. of the reconstruction norm (normative basis of a particular decision-making process). Such an approach would allow to build a phase model of the operative legal interpretation process, where the following can be distinguished as its basic phases: validating and derivative phase (encompassing the derivative interpretation, also including the clarification of the meanings and the reconstruction of the basis of the decision-making process, extending up to the elements which are indispensable for determining the content of the act of will to apply the law, i.e. the right classification of particular facts and assessing any consequences of these facts". It would be the most adequate for this approach, therefore, to provide it with a name (term) of "validation-derivation" concept of legal interpreation. ${ }^{5}$

This approach is based on the assumption that legal interpretation basically takes the form of the activities and reasoning (analytical) processes, leading to the reconstruction of the legal norm from the given norm-creating facts; the notion of legal interpretation, in this case, also covers the activities associated with the determining of the source of law. ${ }^{6}$ In the validation-derivation approach the following detailed phases of the operative legal interpretation are distinguished: 1. Validation assessments referring to the legal text, precedence cases, and to the extra-legal criteria; 2. Introductory system derivation - the assessment of the stem (the basis) of the decision (the act of will) from the basic legal provisions; 3 . The complex system derivation - the addition of the elements obtained as a result of the analysis of the inter-relations between the basic legal regulations and the subsidiary legal

4 A. Redelbach, S. Wronkowska, Z. Ziembiński, Zarys teorii państwa i prawa, Warszawa 1992, p. 198.

${ }^{5}$ L. Leszczyński, Zagadnienia teorii stosowania prawa. Doktryna i tezy orzecznictwa, Kraków 2001, p. 114.

6 M. Kordela, “Aksjologiczna wykładnia prawa”, [in:] Polityczność nauki prawa i praktyki prawniczej, eds. A. Bator, P. Kaczmarek, "Przegląd Prawa i Administracji” 110, Wrocław 2017, p. 153. 
regulations; 4. Extra-system derivation - conducted with the help of rules of the semi-adequate validation-derivation concepts (the recapturing of the norms from precedence cases and on the basis of extra-legal criteria); 5. Clarification is obtained "along" the validation and derivation assessments; 6 . The subsumptive reduction. ${ }^{7}$ In the validation-derivation approach there exists quite a wide openness (readiness to accept) any other additional sources, such as international public law, European law, extra-legal criteria and other decisions to apply the law.

\section{THE PROBLEM OF LEGAL INTERPRETATION IN EU LAW}

In the European Union law, what definitely prevails, are the extra-linguistic legal interpretation rules, which take the form of a functional and axiological legal interpretation. They evidently occur already at the introductory stage of validating the legal interpretation. The cause of this is that all the languages of the EU Member States have equal rights, and thus all of them must be taken into consideration, whenever the legal texts of the EU legal system are being assessed. What is meant here, are not so much ethnic languages, but their modified versions, called legal languages, or languages of law; and it also happens that in some countries the texts are written in the same ethnic language, but in different legal languages (for instance Germany, Austria). In view of this, doubts arise if one can talk at all about isomorphy, i.e. of the so-called direct understanding of the legal text. Besides, the jurisdiction of the Court of Justice of the European Union (CJEU) definitely shows that the verbal interpretation of the EU legal regulations does not constitute the limit of the legal interpretation and thus one can abstain from it. This happens when such an attitude is required by the axiological basis, which the European Union has respected, or just because of the cohesion and effectiveness of this legal system. It must also be noted, that the teleological legal interpretation is largely simplified in this system, because of the lengthy introductions (arenga), put before the main texts of the normative legal acts, explaining the functions which the given act is to serve. ${ }^{8}$ The priority of the teleological legal interpretation emerges from the circumstances, that the EU Court of Justice has no jurisdiction to decide over the issues of the correctness of the legal basis of a given directive, on the basis of two usually preferred types of the legal interpretation. This is, in turn, caused by the fact that the doubts cannot be eliminated with the aid of language (lexical) legal interpretation, invoking the widely understood linguistic context of a given legal regulation and of the norm, which is being interpreted on the basis of this regulation, allowing for the elimina-

7 M. Zajęcki, "Dwie próby operacjonalizacji derywacyjnej koncepcji wykładni prawa (rozdział IX)”, [in:] M. Hermann, S. Sykuna, Wykładnia prawa. Tradycja i perspektywy, Warszawa 2016, pp. 153-154.

8 Z. Radwański, "Uwagi o wykładni prawa cywilnego", Ruch Prawniczy, Ekonomiczny i Socjologiczny 71, 2009, no. 1, p. 12. 
tion of the so-called semantic shadow, through applying the meaning rules, or the syntactic rules; this interpretation is especially important because of the existence, in the EU law, of the extended system of the official languages, and because of taking into account the autonomic notions. ${ }^{9}$

The problem of whether literally every text should be submitted to the legal interpretation, or just the texts which are unclear, is legally valid for three basic reasons. First of all, this question delimits the scope of the activities of the EU Court of Justice, which is, according to the Treaty of Rome, competent for interpreting the EU law. Secondly, it is connected with the differentiating between determining the lexical meaning of a given legal regulation and the going beyond the lexical meaning, by the Luxembourg Court, or even questioning this linguistic meaning by the Court. Going beyond the literal understanding of the text is, however, the first step on the way to the extending of the linguistic meaning of this text. The questioning (putting into doubt) of the intuitive responses to the meaning of a particular legal text, or the lack of such intuitive responses, open the possibility of determining the normative meaning of this particular text, divergent from its lexical meaning; this is done on the basis of other legal regulations (other legal acts and provisions). As a result, the possibility to carry out the legal interpretation, implies the possibility of determining the meaning of the law, in isolation from particular legal provisions; this in turn widens the scope of independence of the Court of Justice. The third issue to be mentioned here is that the acceptance (employment) of the clarification concept of the legal interpretation, determines that, in some cases, the courts should not make any legal interpretation at all, and while they do it, they usurp in fact the independence, which they have been denied by the law. The derivative concept of the legal interpretation remains in contradiction with the practice of jurisdiction of both the Polish and EU courts and bodies. Or at least this takes place in the cases when none of these courts or bodies practices extracting the norms from particular legal provisions (as understood within the derivative concept), before applying them. When the court approaches the stage of legal interpretation, it must start both from the meanings of a given regulation, occurring in the Community, as well as it must finally arrive at one of the meanings, which can be acceptable, as a result of the legal interpretation. On its way, within this process, the court can, however, only make use of the directives for legal interpretation, which have been formally accepted in the Community. However the court, especially as powerful as the Court of Justice, has the capability of introducing in the Community its own methods and directives. It can even cause that a given meaning may be classified as unacceptable. In order to do this, the court does not need any formal authority - its own moral authority is enough. For as long as there was no legal interpretation of the Court of Justice, it was accept-

9 J. Ciesielski, "Traktatowe podstawy dyrektyw konsumenckich a orzecznictwo TS”, Europejski Przegląd Sądowy 2013, no. 8, p. 31. 
able to defend oneself with the unclarity of a given legal rule - the acting of an individual, on the basis of the various meanings of a given legal regulation, even if they are later classified as incorrect, has been sometimes classified as acceptable. The clarity of the legal regulations is, however, questioned (called into doubt) more and more often, and this is done only in one direction - in the direction of the stronger EU. ${ }^{10}$ It must be stressed that the role of the prejudical rulings of the Court of Justice of the European Union makes the position of the jurisdiction as a validation argument even more significant. ${ }^{11}$

Currently, the claritas doctrine ${ }^{12}$ - understood as the ideology of the legal interpretation - is a common phenomenon in legal culture, mirrored in the jurisdiction practice of the EU bodies. Generally speaking, the claritas doctrine finds its expression in the demand that lawyers should not submit any of the legal texts, which are characterized by unified (coherent) meaning, to any "interpretation processing". From a practical point of view, this doctrine means the necessity to provide arguments for the thesis about the unclarity of the provided text, before moving to the stage of its interpretation. The aim of this type of ideology is to put a limit to the legal discretional authority. ${ }^{13}$ If the meaning of the legal text has already been subjected to jurisdiction, and if a particular line of jurisdiction practice has already been settled, then we say that a given legal text is clear. It is, however, not clara in the linguistic sense, i.e. in the sense mentioned in the clarification concept of legal interpretation; it is rather just an assumption of the fact that there exists an agreement between the judges as to the meaning of the law. In the clarification theory there is continued support for aiming at the objectification of the legal text's meaning, however, only in the justification context. ${ }^{14}$ What is sometimes taken into consideration is the basis of the legal interpretation itself. We make an interpretation of the legal text when the sense of a legal regulation raises doubts, i.e. clara non sunt interpretanda; so, for instance, when a given regulation is not sharp, or when it is unclear or ambiguous. According to the declaratory theory of law, in such a case the interpreter should limit himself just to stating that a given legal provision shows a fault of a particular type, while the task of its elimination should be left to the legislator. However, it is beyond any doubt, that when the interpreter comes to the conclusion that a given legal regulation can be ascribed several meanings, then he will have to choose, on his own, one of these

10 P. Marcisz, Koncepcja tworzenia prawa przez Trybunat Sprawiedliwości Unii Europejskiej, Warszawa 2015, pp. 46, 54, 60-61, 69, 118.

11 L. Leszczyński, "Wykładnia operatywna (podstawowe właściwości)", Państwo i Prawo 2009, no. 6, pp. 18-19.

12 A. Kozak, Granice prawniczej władzy dyskrecjonalnej, Wrocław 2002, p. 82.

13 J. Wyrembak, Zasadnicza wykładnia znamion przestępstw. Pozycja metody językowej oraz rezultatów jej użycia, Warszawa 2009, p. 108.

14 M. Zirk-Sadowski, "Problemy wyboru pomiędzy konkurującymi modelami wykładni prawa”, Przeglad Prawa i Administracji 104, 2016, p. 160. 
meanings as the right (adequate) one. In the legal interpretation, the interpreter is more of a therapist than just a diagnostician, and this role is also difficult to reconcile with the foundations on which the declaratory theory of law is based. ${ }^{15}$

The EU law accepts the principle clara non sunt interpretanda. In the interpretation of the CJEU, which, by the way, has been shaped under the evident influence of French jurisdiction and doctrine, the principle clara non sunt interpretanda consists of two elements: one of them is called the acte clair principle, and the other the acte eclaire principle. According to the rule of acte clair, if a given text is clear (understandable) in its basic (popular) meaning, then it is not submitted to legal interpretation. ${ }^{16}$ The acte clair doctrine has provided a legal justification for the limiting of the required prejudical speeches, in such a way that the national courts will no longer have to direct requests to the Court of Justice for an interpretation. It also serves to strenghten the position of the court bodies, competent for a given basic (main) case. It is for these very reasons that the acte clair doctrine has entered and found its permanent place among the range of procedural measures employed by the French Conseil d'État. The transfer of this principle by Conseil d'État to the relationships within the scope of the EU law was a consequence of the established practice in the French legal order, but it was also an instrument, serving the enforcement of the autonomy of the national courts in relations with the Court of Justice. The acte clair doctrine soon started to be recognized by the courts of some other Member States, especially in the United Kingdom and Germany, and later in Italy and Belgium. The essence of this approach was the independent resolution in a particular legal case, by the national courts, as to the content of the regulations of EU law applicable to this particular case; this took place, each time, via recognizing the content of the EU regulations as obvious (clear), with a binding and final effect, in case of the settlements made by the courts, the rulings of which do not allow for any legal remedies (appeal), without resorting to the preliminary CJEU rulings. ${ }^{17}$

The acte eclaire principle shows, in turn, that a text, which can, admittedly, raise doubts, but these doubts have already been clarified at the earlier stage, in the jurisprudence of the Court of Justice of the European Union, is also not subject to legal interpretation. In both cases, the courts of the Member States should not bring requests to the Court for a preliminary ruling; and in case of bringing a request before CJEU, the Court is not bound to draft such a ruling. It is, however, relevantly stressed that because of the language pluralism in the European Union, as well as because of the fact, that the aim and politics of the European Union may evolve along time, the

15 L. Morawski, Główne problemy wspótczesnej filozofii prawa. Prawo w toku przemian, 4th ed., Warszawa 2005, p. 276.

16 L. Morawski, Zasady wykładni prawa, Toruń 2006, p. 268.

17 E. Piontek, "Doktryna i praktyka acte clair a wspólnotowy porządek prawny w kontekście funkcji art. 234 TWE", [in:] Prawo polskie a prawo Unii Europejskiej, ed. E. Piontek, Warszawa 2003, pp. 112-113. 
CJEU approaches the principle clara non sunt interpretanda with much prudence. Also, undoubtedly, the scope of applying this principle is narrower than in the internal law of the Member States. The concept of acte eclaire, which constitutes the basis of the "binding legal interpretation" (in force), does play, in essence, a similar function to that of the principle of stare decisis, operating in the systems based on common law. This concept finds its full employment in the case of preliminary (interpretative) rulings. There are, however, no obstacles to speak of it in the context of the rulings, drafted within the procedures different then the preliminary. The concept of acte eclaire, simply understood as sui generis binding interpretation, can be satisfactorily applied not only to the interpretative rulings of the CJEU. The principle of stare decisis in the EU law, is reflected in the fact, that the national courts are obliged to adjudicate on the basis of the previous rulings of the Court in Luxembourg; however, similarly as it happens in the legal systems, based on the common law model — this principle is limited in some degree. The national court may abstain from the earlier rulings of the CJEU and direct to the CJEU a preliminary question. Similarly, CJEU is not bound with its former resolutions. ${ }^{18}$

On the basis of the legal doctrine in EU law, the term clear is sometimes applied to the cases of isomorphy. This isomorphy, let's remind, occurs when the application of the legal regulations to the factual circumstances of a given matter does not constitute any problems in fact (and is clear in this sense). In these cases, we are dealing with the claritas situation, and thus, there is no need to refer to any interpretation sensu stricto. On the other hand, the difficult case means a case where it is not clear on the basis of which legal regulations the matter, already pending before a court, should be settled. In these cases, we are faced with doubt and the necessity of making an interpretation. The matter, which seems difficult at first glance, may, however, finally turn out to be clear, as it seems difficult only as a result of problematization (problem-making). Additionally, we dispose of the arguments, according to which the Community theory of acte clair has also been based on the assumption that some legal cases have a routine character, and they do not generate interpretative doubts: when a legal regulation is clear, then its simple invoking constitutes the sufficient basis to enable the court's further resolution, without any need to explain, why a given regulation has been quoted in a particular way. The jurisprudence itself may also contribute to the fact that the number of clear cases will grow, with such an effect that the Court will make use of the possibilities, provided to it by the Rules to inform the national court, that a given case has already been explained (clarified) enough, and thus there is no need to make any interpretation in the form of the preliminary ruling. ${ }^{19}$

18 M. Stępień, Systemowość prawa europejskiego, Poznań 2008, pp. 119-120.

19 Z. Brodecki, T.T. Koncewicz, “'Wspólnotowa rozumność' w Trybunale Sprawiedliwości Wspólnot Europejskich”, [in:] Rozumność rozumowań prawniczych, ed. M. Wyrzykowski, Warszawa 2008, pp. 138-140. 
The Luxembourg judge starts the interpretation process from the analysis of the text, as he must start the legal discourse from some stage; however, the legal norm emerging thereof, does not emerge via simple decoding, but it is creatively generated, with the aid of extralinguistic arguments, which are perceived via the prism of a particular legal case. Thus, we deal here with a permanent abstaining from the core principle of the legal interpretation, clara non sunt interpretanda, in favour of the principle omnia sunt interpretanda, the latter perceived as contradictory to the practice of law application. This happens for three reasons. One is the result of a relatively large number of quite vague statements in EU law. The other is the necessity for such an interpretation of the EU law, which would guarantee that this law can undergo the real and unlimited continuous evolution. Yet another factor is the obligation present in this system, to apply the same rules of the EU law in all the official languages of EU. ${ }^{20}$ The attempt to replace clara non sunt interpretanda with the paremia omnia sunt interpretanda in the context of European law has its critics, who postulate to exercise adequate caution whenever one uses the arguments of the derivative interpretation concept, with regard to the preliminary questions, addressed by the judges of the national courts to the Court of Justice. This, in turn, takes place because refraining from the principle of acte clair could lead to the paralysis of the jurisprudence, based on Art. 267 of the CJEU.

\section{MOVING TOWARDS THE DERIVATIVE LEGAL INTERPRETATION IN EU LAW}

The attempt to construct the model of pro-Community legal interpretation is, in fact, the attempt of theoretical approach of the operative interpretation of the national law, in a certain unique interpretative situation. It has been acknowledged, in the theory of law, that the legal interpretation made by the courts and other bodies applying the law, has the name of operative (functional) legal interpretation. Besides, the concrete character of this interpretation has been emphasized in legal theory. The duty of the pro-Community legal interpretation has been in fact imposed on the courts and other bodies which apply the law. Thus, the pro-Community legal interpretation has been referred to as the operative (functional) interpretation of the judicial bodies of the Member States. ${ }^{21}$ Whenever an EU legal case emerges, it automatically generates the duty, ex officio, to take into account the EU law, in the process of formulating the normative basis for the ruling drafted by the national court. This means the necessity of referring to the system of the legal sources of the EU - the primary legislation, secondary (derived) law

20 K. Scheuring, Precedens w orzecznictwie Trybunału Sprawiedliwości Unii Europejskiej, Warszawa 2010, p. 120.

21 K. Płeszka, Wykładnia rozszerzajaca, Warszawa 2010, pp. 266-267. 
and international EU law, as well as the subsidiary sources in the form of the jurisprudence of the Court of Justice of the European Union. In view of that, the validation assessment becomes more difficult. Rarely does it happen that no interpreation doubts arise. This, in turn, justifies the necessity of the cooperation between the national courts and the Court of Justice in Luxembourg. In case of the legal interpretation of EU law, this interpretation is to serve, additionally, to fill the gaps in the EU legal regulations, and to prevent the potential cases of collision with the legal norms of all the Member States of the European Union. ${ }^{22}$ In view of this, the reconstruction of the Community interpretation scheme, based on the model of the interpretation practice of the Court of Justice, may constitute in numerous cases a difficult or impossible interpretative task to be undertaken by the national court. It is for this reason, that the preliminary procedure, pursuant to Art. $267 \mathrm{CJEU}$, is so important. This institutionalized mechanism allows the national courts to remove doubts as to the classification of the states of affairs (status quo), i.e. the states which represent a denotation of the EU norms. This is done by the body competent for interpreting the EU law — the Court of Justice of the European Union.

Looking for the derivative aspect in the interpretation process of EU law, we must take into account that the creator of the derivative concept, Maciej Zieliński, ${ }^{23}$ while constructing his derivation model of the legal interpretation of the national law, has also included in it the directive of the pro-Union interpretation, which he classified as the system-interpretation directive. In fact, he has assigned to it the rank of a rule. This rule is applicable at the last stage (phase) of the legal interpretation, i.e. at the perceptive stage. The rule marked in the derivative algorithm with the number 21 (the second rule of the system-interpretation within the perceptive stage) demands - in accordance with the vertical system-directives - to check, among others, if the content of the norm is in agreement with the norms within the EU law. On the other hand, rule 22 obliges to dismiss any understanding of the interpreted phrase, which would generate the vertical norms conflict. Within the derivative model of the legal interpretation, the system-directives of the interpretation are applicable only in the first variant of the perception stage; i.e. only in the cases when the effect, obtained with the aid of the language directives of the legal interpretation, is not unequivocal. The analysis of the views of Maciej Zieliński allows for the following conclusions:

1. The pro-Union interpretation is not a separate scheme of proceedings, but it is a fragment of the model of the national law.

22 A. Kalisz, "Stosowanie i wykładnia prawa Unii Europejskiej”, [in:] Zagadnienia stosowania prawa. Perspektywa teoretyczna i dogmatyczna, eds. W. Dziedziak, B. Liżewski, Lublin 2015, pp. 195-196.

23 M. Zieliński, Wykładnia prawa. Zasady - reguly - wskazówki, 7th ed., Warszawa 2017, p. 322 . 
2. In the derivative model, the arriving at the interpretation which is coherent with the EU norms takes place in the form of making the following comparison: between the norm-shaping expression, obtained from the legal text, which had been drafted by the Polish legislator, with an adequate norm of the EU law.

3. The derivative model, while positioning the duty of taking into account the EU law among the system-directives of the legal interpretation, automatically assigns to the pro-Union interpretation the exclusively limiting feature. The quoted directive is triggered only in the case of ambiguities in the legal text, drafted by the national legislator, and its role is to help to choose one of the alternative linguistic solutions. The issue of the incompatibilities of the linguistically unequivocal norms of the national law with the EU law, has been moved to the sphere of solving the validation problems. The derivation model does not take into account the need to invoke the complex system of values, ascribed to the EU legislator, in the case of the unequivocal effect of applying the language interpretation. This can result either from the assumption about the identity of the axiological systems, ascribed to the national legislator and EU legislator; or it can result from ignoring the system of values, represented by the European legislator, in the case, when the effect of the legal interpretation is unequivocal.

4. The derivative model does not describe how the comparison should be made between the norm-shaping expression, obtained from the legal text, drafted by the Polish legislator, with the norm of the EU law. It remains unknown, what activities should be undertaken by the interpreter, so that he can carry out correctly the process of comparison between the two norms. Difficulties can already arise when one is trying to make an interpretation of a particular norm of the EU law. The following questions can be asked here: is it possible to obtain such a norm exclusively with the aid of the validation activities, or is it possible to accept another interpretation, in accordance with another interpretation concept? Maciej Zieliński himself accepts, in this sphere, an alternative method of obtaining the norm, i.e. different from the derivative one, while accepting the autonomy of the EU interpretation culture. Zieliński points out that the legal interpretation of the national legal regulations should be proceeded with a semi-interpretation of the EU legal regulations, which should be based on taking into account the characteristic features of the texts of the EU legal texts, as well as on accepting the EU interpretation culture, with its emphasis on the functional directives. In view of this, there emerges a breach in the unified and coherent derivative model of the legal interpretation. On the one hand, in the case of the interpretation of a norm, emerging from the legal text, drafted by the national legislator, the interpreter should closely follow the derivation algorithm. On the other hand, in the case of acquiring a norm of the EU law, the body undertaking the legal interpretation may, or even should, abstain from making the interpretation on the basis of the derivation model. The situation described herein serves 
to contradict the thesis about the universality and absoluteness in the context of the derivative concept. ${ }^{24}$

The two-level character of the texts, pointed out by Maciej Zieliński, requires primarily a transition from the level of the legal provisions to the level of the norms. In order to obtain this, it is necessary to find the elements of the norm, which rarely happen to be included in one single legal regulation. The next step is to reconstruct the norm-shaping expression, i.e. the complex (and complete) expression, where its completeness is judged from the point of view of structure. This is done via looking for a particular incomplete frame legal rule (legally incomplete, which at least expresses the duty to undertake a particular behaviour), the right supplementary provisions, which can be either the provisions of the national law, or EU law. Because of the fact, that the law is "being written" via texts, and not via the provisions, what we encounter, apart from the syntactic segmentation, is the additional semantic segmentation. The latter, as we remember, requires from the interpreter the finding, for a particular legal provision, the modifying legal regulations (of the national law or other law, eg. EU law), which would modify its content. ${ }^{25}$ Therefore, the derivative concept of the legal interpretation of Maciej Zieliński enables both getting to know and solving the problems, which emerge along the process of legal interpretation and application of the EU law, on the level of the Member States. The EU law determines the primary, secondary (derived) and complex legal status of the national bodies. This should be connected with the rule of direct application/effect. The EU legal regulations express the norms, including the elements of these norms, which make the national bodies their addressees, beneficiaries or the authorised persons.

According to the doctrine the legal interpretation made by the Court of Justice of EU should mirror the wide, validation-derivation approach to the legal interpretation. This is place due to the specific character of the sources of the EU law, and due to the evident, in this case, validation element, which excludes the case of isomorphy. The considerations concerning the validation issues, taking into account the versatility of the sources of EU law, are very valuable, especially in view of fact that the sources of the EU law differ in large degree from the sources of the national law. ${ }^{26}$

It is obvious, that in order to assess if a given legal regulation is or is not clear, one can first make validation assessments. This, however, can appear problematic because of the general conditions of the specific (polycentric) system, characteristic for the sources of the EU law. The joint approach itself, to both the validation assessments and the interpretative ones, does not generate as many

24 W. Rowiński, "Dyskusja nad modelem wykładni prounijnej w polskiej nauce prawa", Przegląd Prawniczy Uniwersytetu im. Adama Mickiewicza 2012, no. 1, pp. 16-18.

25 A. Chodun, "Koncepcja wykładni prawa Macieja Zielińskiego", Ruch Prawniczy, Ekonomiczny i Socjologiczny 78, 2016, no. 4, p. 59.

${ }^{26}$ K. Paluszek, Komparatystyka językowa jako narzędzie interpretacyjne Trybunału Sprawiedliwości Unii Europejskiej, Katowice 2017, unpublished doctoral dissertation, p. 21. 
doubts as are generated by the negation of the isomorphy; this isomorphy is here understood as the condition derogating the legal interpretation, which is perceived as a consequence of the validation-derivation approach. The validation assessments take place in the process of every application of the EU law, even if the national courts do not make use of the help of CJEU. But the interpretation itself does not use the help of the Court of Justice, i.e. no requests are directed to the Court for the interpretation. Accepting the derivative concept of the legal interpretation in the EU context implies the rejection of the doctrine of acte clair which seems useful from the point of view of the development of the cooperation of the national courts with the CJEU. The application of the derivative approach seems irreconcilable with the doctrine of acte clair. On the other hand, the interpretation practice of the EU law, connected with the multiplicity of the bodies who perform legislation functions, the obligation for making the interpretation pro-Community (friendly and uniform), the spread of technology, regarding the majority of the EU legal regulations, creates real challenges for the derivative concept.

\section{BIBLIOGRAFIA}

Bogucki O., Model wykładni funkcjonalnej w derywacyjnej koncepcji prawa, Szczecin 2016.

Brodecki Z., Koncewicz T.T., “'Wspólnotowa rozumność’ w Trybunale Sprawiedliwości Wspólnot Europejskich", [in:] Rozumność rozumowań prawniczych, ed. M. Wyrzykowski, Warszawa 2008.

Brzeziński P., "Konstytucyjne prawo do ochrony zdrowia w świetle derywacyjnej koncepcji wykładni”, Ruch Prawniczy, Ekonomiczny i Socjologiczny 73, 2011, no. 1.

Ciesielski J., "Traktatowe podstawy dyrektyw konsumenckich a orzecznictwo TS", Europejski Przeglad Sadowy 2013, no. 8

Chodun A., "Koncepcja wykładni prawa Macieja Zielińskiego", Ruch Prawniczy, Ekonomiczny i Socjologiczny 78, 2016, no. 4.

Kalisz A., "Stosowanie i wykładnia prawa Unii Europejskiej”, [in:] Zagadnienia stosowania prawa. Perspektywa teoretyczna i dogmatyczna, eds. W. Dziedziak, B. Liżewski, Lublin 2015.

Kozak A., Granice prawniczej władzy dyskrecjonalnej, Wrocław 2002.

Kordela M., "Aksjologiczna wykładnia prawa", [in:] Polityczność nauki prawa i praktyki prawniczej, eds. A. Bator, P. Kaczmarek, "Przegląd Prawa i Administracji” 110, Wrocław 2017.

Leszczyński L., "Wykładnia operatywna (podstawowe właściwości)", Państwo i Prawo 2009, no. 6. Leszczyński L., Zagadnienia teorii stosowania prawa. Doktryna i tezy orzecznictwa, Kraków 2001. Marcisz P., Koncepcja tworzenia prawa przez Trybunat Sprawiedliwości Unii Europejskiej, Warszawa 2015.

Morawski L., Gtówne problemy wspótczesnej filozofii prawa. Prawo w toku przemian, 4th ed., Warszawa 2005.

Morawski L., Zasady wykładni prawa, Toruń 2006.

Paluszek K., Komparatystyka językowa jako narzędzie interpretacyjne Trybunału Sprawiedliwości Unii Europejskiej, Katowice 2017, unpublished doctoral dissertation.

Piontek E., "Doktryna i praktyka acte clair a wspólnotowy porządek prawny w kontekście funkcji art. 234 TWE", [in:] Prawo polskie a prawo Unii Europejskiej, ed. E. Piontek, Warszawa 2003.

Płeszka K., Wykładnia rozszerzająca, Warszawa 2010. 
Radwański Z., "Uwagi o wykładni prawa cywilnego", Ruch Prawniczy, Ekonomiczny i Socjologiczny 71,2009 , no. 1 .

Redelbach A., Wronkowska S., Ziembiński Z., Zarys teorii państwa i prawa, Warszawa 1992.

Rowiński W., "Dyskusja nad modelem wykładni prounijnej w polskiej nauce prawa", Przegląd Prawniczy Uniwersytetu im. Adama Mickiewicza 2012, no. 1.

Scheuring K., Precedens w orzecznictwie Trybunału Sprawiedliwości Unii Europejskiej, Warszawa 2010 .

Siwek K., "Komunikatywność tekstu prawnego a derywacyjna koncepcja wykładni prawa (aspekt rozumienia normy sankcjonowanej)", Ruch Prawniczy, Ekonomiczny i Socjologiczny 78, 2016, no. 4.

Stępień M., Systemowość prawa europejskiego, Poznań 2008.

Wyrembak J., Zasadnicza wyktadnia znamion przestępstw. Pozycja metody językowej oraz rezultatów jej użycia, Warszawa 2009.

Zajęcki M., "Dwie próby operacjonalizacji derywacyjnej koncepcji wykładni prawa (rozdział IX)", [in:] M. Hermann, S. Sykuna, Wyktadnia prawa. Tradycja i perspektywy, Warszawa 2016.

Zieliński M., Wykładnia prawa. Zasady - reguły — wskazówki, 7th ed., Warszawa 2017.

Zirk-Sadowski M., "Problemy wyboru pomiędzy konkurującymi modelami wykładni prawa", Przeglad Prawa i Administracji 104, 2016.

\section{DERYWACYJNA KONCEPCJA WYKŁADNI W PRAWIE UE}

\section{Streszczenie}

Derywacyjna koncepcja wykładni autorstwa Zygmunta Ziembińskiego i Macieja Zielińskiego jest jedną z dwóch, obok semantycznej intensjonalnej (klaryfikacyjnej) sformułowanej przez Jerzego Wróblewskiego, powstałych w powojennej polskiej teorii prawa normatywnych koncepcji wykładni. W doktrynie prezentowany jest pogląd, zgodnie z którym wykładnia dokonywana przez Trybunał Sprawiedliwości Unii Europejskiej miałaby odpowiadać szerokiemu, walidacyjno-derywacyjnemu ujęciu wykładni, a to ze względu na charakter źródeł prawa UE oraz wyraźny w tym przypadku element walidacyjny wykluczający sytuację izomorfii. Rozważania dotyczące kwestii walidacyjnych, uwzględniające różnorodność źródeł prawa unijnego, są bardzo cenne, szczególnie wobec faktu, że źródła prawa Unii Europejskiej bardzo różnią się od źródeł prawa krajowego. Akceptacja ujęcia derywacyjnego wydaje się nie do pogodzenia $\mathrm{z}$ doktryną acte clair. Z drugiej strony praktyka interpretacyjna prawa Unii Europejskiej, związana z wielością podmiotów pełniących funkcje prawodawcze, wymogiem wykładni prowspólnotowej (przyjaznej, jednolitej), technicyzacją większości regulacji prawa Unii Europejskiej oraz wielojęzycznością przepisów prawa unijnego stawia wyzwania przed koncepcją derywacyjną.

Słowa kluczowe: wykładnia derywacyjna, sytuacja wykładni, prounijna interpretacja, doktryna acte clair, walidacyjno-derywacyjna wykładnia 